Article

\title{
Influence of Land and Water Rights on Land Degradation in Central Asia
}

\author{
Ekaterina Strikeleva *, Iskandar Abdullaev and Tais Reznikova \\ The Regional Environmental Centre for Central Asia (CAREC), Almaty A15D5B3, Kazakhstan; \\ iabdullaev@carececo.org (I.A.); treznikova@carececo.org (T.R.) \\ * Correspondence: estrikeleva@carececo.org; Tel.: +7-778-888-9075
}

Received: 11 July 2018; Accepted: 11 September 2018; Published: 14 September 2018

\begin{abstract}
Land degradation is a key issue for Central Asia as an agrarian region. Land degradation in Central Asia is usually seen as a technological challenge and corresponding solutions are associated with the improvement of land-use technology. However, the reality is more complicated and multi-faceted. Institutional aspects of land degradation in the region are more prominent and yet unnoticed. De-linked water and land rights, increased land production functions, water infrastructure degradation, a lack of water-use monitoring, and a lack of knowledge among water users constitute the major institutional aspects of land degradation in Central Asia. This paper looks at the linkages between water and land rights and the main aspects of land degradation. The research was built on a literature review, including internationally funded project reports and in-house investigations.
\end{abstract}

Keywords: degradation; water management; land management; Central Asia; water and land rights

\section{Introduction}

Central Asia (CA) is known as an area of productive irrigated lands and pastures. However, currently, the region is facing serious land degradation challenges. More than half of $8 \mathrm{mln}$ ha of irrigated land and half of pastures in CA are degraded to various degrees [1]. As a biophysical process, land degradation has been examined quite well for Central Asia [1-4]. On the one hand, Central Asia's reduced productivity and potential economic losses due to land degradation are comparable with the effects of climate change [3]. In order to understand the scope of land degradation, it could be described in terms of the widely known climate change. By 2050, the region may face severe water shortages due to climate risks, and land degradation may produce severe food shortages. On the other hand, experts note that changing management schemes as well as legislation on land and water rights also contribute to increased land degradation $[5,6]$. This aspect of land degradation has been rarely studied by either international or national scientists.

Historically, beginning from the Tsarist period until the post-Soviet era, water and land rights in Central Asia underwent change several times. In every such instance, institutional reforms affected land and water use, and as a result led to land degradation. Since ancient times, land and water rights in Central Asia have been interlinked. The landowner was entitled to pre-determined water rights. However, in the 1930s, water and land rights were disintegrated. Land became one of elements of the system of production and almost lost its role as part of nature. Due to large-scale land degradation and loss of productivity of land resources in traditional agricultural areas, the Soviet state launched new "virgin land" development programmes to extend agriculture into new areas. By the 1990s, the degradation of land resources reached disastrous proportions, and reclamation of degraded land became the focus of state agencies responsible for agricultural production. However, due to institutional disintegration and a lack of financial means, land degradation continued in CA. Moreover, the newly established states of Central Asia initiated social, economic and environmental 
reforms shifting away from the Soviet system. Ownership and production forms in agriculture changed-instead of a collective system, land ownership transformed into an array of different forms of individual land use $[7,8]$.

This article looks at three historical intervals of the development of Central Asian countries and four types of land degradation. The publication aims to analyze the relations between water and land rights during the different periods of Central Asia's development and their impact on land degradation. The research methodology applied consisted of system analysis with elements of institutional analysis on various types of land degradation. The empirical section of this paper contains data and information gathered by the authors from literature, internationally funded project reports and their own investigations.

\section{Concept and Methodology}

Land degradation in Central Asia has serious social and economic impacts. The condition of the environment directly influences the living standard and health of the population, especially its socially vulnerable segments [9]. Land degradation makes rural populations increasingly vulnerable, as well as making them further exploit land resources for short-term production and benefits.

The Aral Sea catastrophe is a famous example of the influence of the Soviet management system on land degradation. Salt pollution had significant adverse effects on the agricultural sector. Approximately 1.5 bln tons of salt and dust from the drained bottom of the Aral Sea distributed over about $3.5 \mathrm{mln}$ ha of land, mostly in downstream areas [8,10].

Large-scale irrigation systems built during the Soviet period led to large water losses and, consequently, to secondary land salinization. For example, by 1980, in Turkmenistan approximately 50,000 ha of land was abandoned annually due to degradation [11].

Land degradation in Kazakhstan poses a huge problem in all administrative areas. The total area of degraded land is estimated to comprise $66 \%$ of the national territory, i.e., over $48 \mathrm{mln}$ ha $[1,12]$. Significant pasture degradation due to over-grazing is present in Kyrgyzstan (30\%), Tajikistan (89\% for summer pastures and $97 \%$ for winter pastures) and Turkmenistan (70\%). In Uzbekistan, about half of irrigated land was salinized by 2007 [1]. Every year, economic losses from land degradation make up $3 \%$ of the GDP for Kazakhstan and Uzbekistan, $4 \%$ for Turkmenistan, 10\% for Tajikistan and $11 \%$ for Kyrgyzstan [13].

After the collapse of the Soviet Union, the process of land degradation has continued due to different changes of water and land management. The current land degradation trends remain and progress due to the "business as usual" model. At the same time, the scale of land degradation is multiplied by climate change impacts [14].

This study focused on water and land management systems, mechanisms of interaction and the identification of regularities. The purpose of this study was to determine the impact of changes in land and water management on land degradation. The research looks at water and land reforms in Central Asian countries and how they influence different types of land degradation.

The main questions of this study were formulated as follows:

- What are the features of the current management systems of land and water rights in Central Asia? How do they interact?

- How did the system of land and water rights change after the CA countries gained independence? What is the impact of these changes on land degradation?

This study examines the corresponding land and water management systems and ongoing reforms in the land and water sectors, as well as retrospectively analyzing the changes in land and water rights in the course of the last 100 years in Central Asia. The research is based on a literature review on the issues of water and land management on the one hand, and on land degradation aspects on the other. The authors tried to identify interactions between these two aspects. The authors used statistical data available for the period of study, several internationally funded project reports, publications, archive 
materials, and their own investigations based on the experience of projects implementation in Central Asian countries.

Various managerial decisions were considered as well as their impact on the use of land and water resources. At the same time, this publication gives a general overview on the problems and relations between land and water resources and does not determine optimal solutions. Conceptual and scientific basics of the land degradation problem are key to developing solutions. This publication can be used in future research to develop a deeper understanding of different types of land and water management on different types of land degradation.

\section{Results}

\subsection{Historical Overview of Land-Water Right Systems in Central Asia}

During the past 70 years, land has been the major driver behind socio-political changes in rural Central Asia. Political system changes were among the core factors affecting land ownership and led to the emergence of its new forms. Land ownership slightly changed during the Tsarist period (1861-1917) and totally transformed during the Soviet period (1917-1991). During the post-Soviet period (1991 onwards), the independent Central Asian states continued the transformation of their land ownership and management systems [15-18].

Lands rights in Central Asia underwent three major changes, starting from the Tsarist period until the post-Soviet time, and in each instance land rights affected water rights (Figure 1).
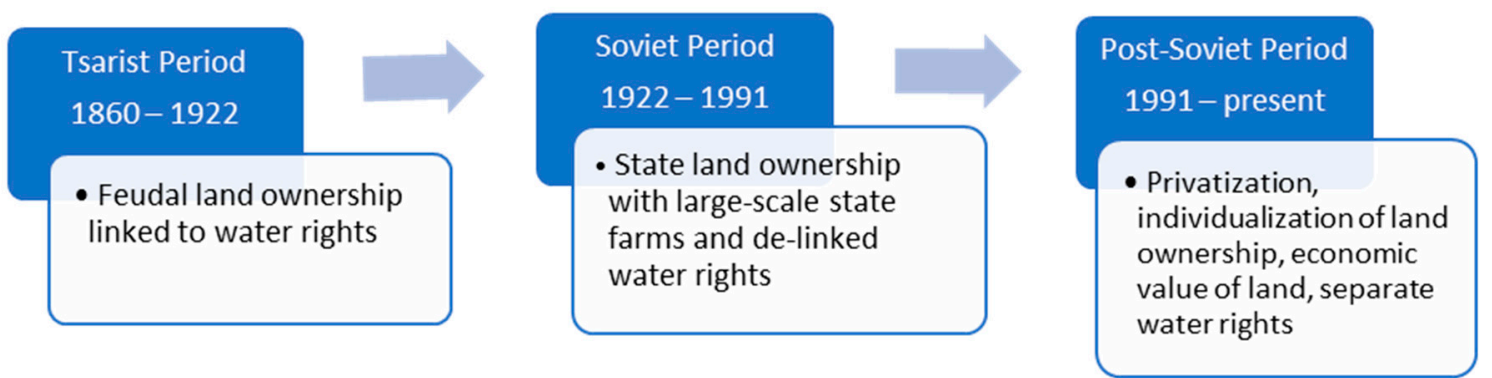

Figure 1. Changes in land and water rights. Source: prepared by authors based on a literature review.

\subsubsection{Tsarist Period}

During the Tsarist period, water management was customary and land arrangements were based on historical rights. The "mirab" — water master—was a person selected by land owners to observe the overall distribution of water among water users. Land not only had production value but was also deemed a family asset and had economical value. However, land productivity was rather low and fallow areas were abundant. Local populations were engaged in subsistence farming and grew mostly food crops. A lot of land was not used and Tsarist Russia tried to use as much of it as possible for cotton production. Land and water rights were closely linked and, thus water distribution was strictly followed by land ownerships. All settlements had to follow the Sharia (Islamic) Water Law regulating water governance $[11,18-20]$.

In the early 20th century, the agrarian policy implemented by Tsarist Russia led to a gradual change in the ratio of nomadic and settled populations. The traditional forms of agriculture became weak and cotton production increased quickly. The reforms by the Russian government altered overall socio-political life. The number of individual/private land users increased [11,21]. During that time, huge areas of irrigated land were allocated for cotton production [11]. The demand for and use of water increased, land ownership was changing; former nomads and newcomers from other parts of Russia were awarded new land rights. That was the time when land degradation started and productivity dropped in the newly settled areas. 
In an attempt to legalize and rationalize existing land and irrigation practices, water resources were de jure nationalized. The Tsarist authority did not realize how important access to water was for the agrarian society of Central Asia. At that time, locally, nothing changed in the customary water management [7].

\subsubsection{Soviet Period}

In the early Soviet period, the political and security-associated significance of irrigated land was evident in the Bolsheviks' attempt to pacify the Fergana Valley. Initially, the changes in the land rights system were insignificant. This fact was also key during the national delimitation process of 1924-1936 when the borders of the CA republics were demarcated [8].

In the late 1920s, water-land reforms destroyed the custom-based relations and individual land ownership rights. The collectivization unfolded extremely quickly and ignored the traditional lifestyles and farming practices. The right to water and land were inseparable in Central Asia. Disregarding that link formed the basis for the new and devastating water policy implemented along with the collectivization.

The new governments in Central Asia embarked on the large-scale programme of land redistribution with the intention of sweeping away the traditional patterns of land tenure. The Soviet water policy of that period was characterized by single-purpose water use, centralized decision-making and planning. The Central Asian republics were ordered to devote their available resources, including land and water, to cotton growing.

At the time, the population and the area of irrigated land in certain provinces, mostly in the Fergana Valley, significantly increased. Fifty percent of the population of Central Asian Republics lived on $20 \%$ of their territory, i.e., in the Fergana Valley, Lower Zarafshan and the Tashkent-Khojand Corridor [8]. Those were the primary and conventionally irrigated areas that demonstrated the relationship between population pressures and competition for limited access to water and fertile land.

The transformation of land ownership during the Soviet period was marked by the collectivization of production and de-privatization of land. A major breakthrough in land relations happened during the 1930s-1940s: collective farms, or Kolkhozes, became the main landowners in the former Soviet Union $[11,20,22]$. Water was also nationalized and became state property.

In the 1930s-1960s, the agricultural policy of the Soviet Union focused on the development of "virgin lands". As a result, Central Asia became a monocrop farming system with cotton as the major crop and, thus lost its food self-sufficiency. Moreover, cotton cultivation caused further soil degradation and loss of land productivity [7].

Several large-scale irrigation systems were built in CA during the Soviet era. In the early 1970s, the Kolkhozes transformed into large Soviet farms (Sovkhozes) occupying up to 100,000 ha of land. The Sovkhozes specialized in single-type production, e.g., cattle husbandry, poultry, vineyards, rice, wheat or cotton [23]. Therefore, within Sovkhozes, land was intensively used for one or two crops for a long time, leading to the decline of soil organic elements, salinization and erosion.

\subsubsection{Post-Soviet Period}

Since 1991, the countries of Central Asia have been developing their independent national economies based on different priorities and schemes. Nevertheless, to a significant extent, they remain agrarian with natural resources still playing an important role [24]. Social and political transformations are leading to changes in land and water resources governance and management.

CA countries have launched land reforms with the aim of dismantling the Soviet land management system. The privatization and individualization of land ownership forms the foundation of reforms taking place in post-Soviet Central Asia.

The land reforms of the 1990s were marked by a complete shift of the economic model with regard to rural development in Central Asia. New states were driven by nation-building priorities, seeking to increase the economic value of their national resources, including land. Gradually, collective farms 
were disbanded and land was handed over to private users based on various country-specific legal arrangements [8]. Although individual (private) land ownership could represent the best model in terms of maintaining land resources, the institutional arrangements in place do not provide sufficient incentives for effective land use.

\subsection{Main Types of Land Degradation}

Currently, land degradation in Central Asia represents a severe and multi-faceted process [25]. Land tenure arrangements, including tenure security, take a special place among the institutional aspects of land degradation as they impact farmers' land management decisions. The management model or the actual way the land is managed-privately or communally, landholding size and fragmentation, land mortgage options, opportunities to transfer land by sale and/or lease-constitutes an essential element of land tenure $[5,15,16]$.

At present, four major types of land degradation have been well-documented and studied: (1) over-irrigation (salinity); (2) water erosion; (3) over-cropping; (4) over-grazing and erosion of pasture lands [13,25].

Over-irrigation (salinity). Salinity is the main land degradation problem in the region. As of today, 3 of $8 \mathrm{mln}$ ha of irrigated land is subject to different degrees of salinity. Thus, annually, approximately 30,000 ha of irrigated land suffers degradation due to salinization [3,4]. After the collapse of the Soviet Union, land and water rights changed; as a result, the number of farms increased from hundreds to thousands at once. The former employees of the Kolkhozes and Sovkhozes became the new farmers responsible for all farming-related issues. Many of them did not have any farming education [1]. The single farm-level land-water planning units disappeared, and the lack of knowledge on irrigation norms led to the fact that farmers believed that using more water was better. This approach has resulted in chaos and uncontrolled competition for water resources [26]. Increased water competition forced the use of low-quality (saline) water, irregular or over-irrigation, and intensive ground water extraction [27]. Thus, the main reason for large-scale salinity lies in weak institutional arrangements related to land ownership, reclamation services and state agricultural policies [28].

The lack of a farm-level water use monitoring system results in uncontrolled water use and, as a consequence, increased water use. Whereas poor maintenance leads to the incapacity of irrigation systems, subsidizing the sector leads to less incentivization for the farmers to save water [13].

Local-level institutional irregularities of water management are most critical for land degradation. Due to inefficient water resource management, the acreage at the end of irrigation networks does not receive enough water, thus causing even worse salinization and land degradation. For example, the area of saline lands at the tail end of irrigation canals increased by $20-25 \%$ only in the Khorezm region of Uzbekistan [29].

Soil erosion becomes increasingly relevant every year due to water balance among farmers lacking money to maintain corresponding irrigation systems. Inadequate management of irrigation networks leads to significant water losses, breakdowns of irrigation canals, and the washing away of fields [4]. Compared to non-degraded soils, degraded land consumes more water. Therefore, linkages between land degradation and water management are obvious. As we can see, most of the time, degraded lands experience water pressures that indicate the close relationship between land degradation and water (mis-)management.

Intensive cropping. Land privatization and individualization did not yield sufficient outcomes to recover the quality of land resources, and land productivity did not change drastically. Private land investments mostly target production functions (fertilization, irrigation, harvesting, etc.). In the past two decades, the Soviet-period single-crop system was replaced by crop quotas or profit-driven monocrop cultivation. At present, land management is in the hands of landowners, and in three CA countries (Kazakhstan, Kyrgyzstan and Tajikistan) farmers are more or less free to choose their cropping and agricultural operations. However, by different means, national governments do influence farmers' cropping choices via direct state quotas, subsidies, state contracts and/or loans [17,22]. The pursuit of 
immediate profit and short-term benefits is leading to the fast decline of land productivity and the removal of land from agricultural use.

Simultaneously, the size of land plots significantly promotes land degradation. Farmers owning small plots (approx. $1 \mathrm{ha}$ ) are trying to achieve the maximum profit from their land assets.

Over-grazing and erosion of pastures. After the collapse of the Soviet Union, the effective pasture management mechanisms disappeared, and farmers suffered from a lack of economic and organizational capacities to develop distant pastures. The absence of a reliable water supply leads to increased livestock migration from pasture zones to the areas adjacent to rural communities. In order to feed themselves, cattle-breeders use pastures near their settlements as much as possible. As a result, pastures around villages are over-grazed and are subject to severe soil erosion and degradation $[1,4,6,13,30,31]$.

As we can see from the examples above, the current land governance and management framework will require significant reforms to reduce land degradation risks, which are high both because of the overall scale of degradation and their impacts on the stability of the regions' countries.

Based on the previous discussion, the authors describe the influence of three water and land management systems in Central Asia on different aspects of land degradation in Table 1.

Table 1. Linkages between historical periods and different types of land degradation. Source: prepared by the authors based on a literature review.

\begin{tabular}{|c|c|c|c|}
\hline $\begin{array}{c}\text { Land Degradation } \\
\text { Type/Historical Periods }\end{array}$ & Tsarist Period & Soviet Period & Post-Soviet Period \\
\hline Over-irrigation (salinity) & $\begin{array}{l}\text { Land degradation is not an issue. } \\
\text { Strict control of water } \\
\text { distribution by Mirab (water } \\
\text { master). }\end{array}$ & $\begin{array}{l}\text { Minor increase of land } \\
\text { degradation. Use of significant } \\
\text { irrigated acreage against the } \\
\text { background of practically } \\
\text { absent water-saving. } \\
\text { Development of arid land } \\
\text { characterized by high natural } \\
\text { salinity. However, annual } \\
\text { land-washing efforts were } \\
\text { taken to prevent salinity. }\end{array}$ & $\begin{array}{l}\text { Significant increase of land } \\
\text { degradation. Lack of water } \\
\text { use control; lack of } \\
\text { irrigation and reclamation } \\
\text { knowledge of newly } \\
\text { created private farms; } \\
\text { "the more water, the better" } \\
\text { trend. }\end{array}$ \\
\hline Soil erosion & $\begin{array}{l}\text { Land degradation is not an issue. } \\
\text { Traditional irrigation } \\
\text { techniques; strict control by } \\
\text { mirab; absence of large-scale } \\
\text { irrigation systems. }\end{array}$ & $\begin{array}{l}\text { Minor increase of land } \\
\text { degradation. Significant length } \\
\text { of irrigational systems with } \\
\text { multiple earthen canals. }\end{array}$ & $\begin{array}{l}\text { Significant increase of land } \\
\text { degradation. Lacking } \\
\text { system for regular } \\
\text { servicing of irrigation } \\
\text { networks due to a lack of } \\
\text { financial means; wear of } \\
\text { irrigation systems } \\
(30-70 \%) \text {; considerable } \\
\text { water losses during } \\
\text { transportation. }\end{array}$ \\
\hline Intensive cropping & $\begin{array}{l}\text { Land degradation is not an issue. } \\
\text { Agriculture covers the food } \\
\text { needs of only local } \\
\text { communities; absence of } \\
\text { considerable export of goods. }\end{array}$ & $\begin{array}{l}\text { Minor increase of land } \\
\text { degradation. Planned crop } \\
\text { distribution; aspiration to } \\
\text { receive maximum yields; } \\
\text { regional crop specialization } \\
\text { against the background of } \\
\text { observing crop rotation. }\end{array}$ & $\begin{array}{l}\text { Significant increase of land } \\
\text { degradation. Farmers' } \\
\text { desire to get maximum } \\
\text { harvests from small land } \\
\text { plots; lack of crop rotation. }\end{array}$ \\
\hline $\begin{array}{l}\text { Over-grazing and erosion } \\
\text { of pasture lands }\end{array}$ & $\begin{array}{l}\text { Land degradation is not an issue. } \\
\text { Traditional cattle-breeding } \\
\text { based on distant-pasture } \\
\text { grazing; migration of livestock } \\
\text { between pastures. }\end{array}$ & $\begin{array}{l}\text { Land degradation is not an issue. } \\
\text { Controlled increase of } \\
\text { livestock population; } \\
\text { developed system of } \\
\text { distant-pasture livestock } \\
\text { production with equipped and } \\
\text { water-supplied grazing } \\
\text { stations. }\end{array}$ & $\begin{array}{l}\text { Significant increase of land } \\
\text { degradation. Destruction of } \\
\text { pasture water supply } \\
\text { infrastructure; cattle } \\
\text { grazing only near } \\
\text { settlements; uncontrolled } \\
\text { increase of livestock } \\
\text { population. }\end{array}$ \\
\hline
\end{tabular}

As we can see from Matrix 1, different management systems influence land degradation differently. Some issues emerged during the Soviet period and increased significantly in the post-Soviet period. In our research, we suggest that the highest impact is exerted by changing land and water rights, which we will discuss in detail in the next chapter. 


\section{Discussion}

Water and Land Rights

Land governance and management of land resources have been well studied by Abdullaev and Rahmatullaev, Spoor, Veldwisch, and Kandiyoti [19,22,32-34]. Their research focused on the evolving institutional changes affecting land and water use in rural Central Asia. The transformation of land and water rights and their implications for the state of land resources are analyzed in this paper.

Despite having different forms in different countries, land ownership in all countries can be classified into land transactions and use. Unclear land ownership status can influence land use sustainability. For example, a lack of responsibility of individuals within collective land use can undermine their incentives to contribute to collective action [35]. Institutional development and decision-making in the sphere of land management represent important components of building an effective management system and sustainable use of land resources.

In the Soviet period, land governance in Central Asia was traditionally the prerogative of the state. The transition of national agricultures from centralized collective to private farms induced significant institutional changes. Land reforms created a certain vacuum among farmers with respect to agricultural services that were previously provided by the state.

The changes in land ownership in the Soviet period led to changes in decision making on land use, preservation, and production. Land ownership was de-coupled from water rights during the collectivization. That constituted a major change from the Tsarist-period model in irrigated agriculture and had an extremely significant long-term impact on irrigated land management. Preceding water-land rights systems were replaced by the new land production functions $[11,22,33]$ that became the main cause of land degradation in the region. Land lost its value as a private asset. Land ownership by collective farms and the state did not promote private interests, thus farmers lost motivation to protect land and use it most effectively. State regulation of land transactions was rather strict, not allowing any private investment, although agricultural productivity was relatively high.

According to Hodgson [35], the most effective management system is when land and water rights are linked. Yet, in the course of the last two decades, we witness further disintegration of these linkages in CA countries. Under the former collective farms model, land and water rights were both in the hands of the state, and water planning and supply were the responsibility of a single organization: the collective farm. At present, water rights are still vested with the state, but land rights in different forms became individualized and are administered by thousands of farmers. This makes water management and planning scattered. Although Water Users Associations (WUAs) were established to replace former collective farms, they are still weak and incapable of proper water resources planning and management. Therefore, farm-level water management is not streamlined and lacks a single institutional agent, giving ground for uncertainty and competition for water resources among land users [24].

The initial phase (1990-2000) of land reforms in Central Asian countries was accompanied by economic recession, growing unemployment, and greater reliance on the domestic economy. The agricultural sector became the "shock absorber" while national populations were trying to ensure their livelihoods [32]. National governments took on a "gradualist" approach to institutional reforms attempting to control the production of leading export crops, avoid rapid unemployment, and provide decent living conditions for rural communities [36].

After gaining independence, national water management systems faced similar challenges. Irrigation networks were constructed at a time when sovereign boundaries did not affect the decision-making of concerned engineers and politicians. After the collapse of the Soviet Union, the new governments tried to manage their land and water considering the challenges of importing water from neighbors and sharing the existing transboundary network. Thus, during the years of independence, the linkages between water management, land rights and new agricultural policies obtained various novel forms and combinations (Table 2). 
Table 2. Linkages between land ownership, agricultural policies and water systems (Abdullaev, 2016).

\begin{tabular}{|c|c|c|}
\hline Land Ownership & Agricultural Policies & Water Systems \\
\hline $\begin{array}{l}\text { Individual, mid- and long-term lease ( } 49-100 \text { years): } \\
\text { - } \quad \text { Limited inheritance } \\
\text { - } \quad \text { Removal of rights in the case of violating land } \\
\text { code or state-established rules }\end{array}$ & $\begin{array}{l}\text { - } \quad \text { State control, self-sufficiency } \\
\text { - } \quad \text { State quotas for main crops } \\
\text { - }\end{array}$ & $\begin{array}{l}\text { State-led and state-controlled (state-centric): } \\
\text { - Weak Water Users Associations (WUAs) } \\
\text { - } \quad \text { State-funded and state-controlled water } \\
\text { management organizations (WMOs) } \\
\text { - } \quad \text { Territorial water management with some } \\
\text { basin management elements } \\
\text { - } \quad \text { Water is a security issue }\end{array}$ \\
\hline $\begin{array}{l}\text { Individual land ownership: } \\
\text { - Inheritance }\end{array}$ & $\begin{array}{l}\text { - } \quad \text { State presence in agriculture } \\
\text { - } \quad \text { Free choice of crops } \\
\text { - State subsidies }\end{array}$ & $\begin{array}{l}\text { Decentralized water management: } \\
\text { - } \quad \text { Emerging viable WUAs } \\
\text { - } \quad \text { Limited state support } \\
\text { - } \quad \text { Basin management }\end{array}$ \\
\hline $\begin{array}{l}\text { Individual private property: } \\
\text { - } \quad \text { Inheritance } \\
\text { - } \quad \text { Sale or transfer of rights }\end{array}$ & $\begin{array}{l}\text { Free market with low or no state presence: } \\
\text { - } \quad \text { Free choice of crops } \\
\text { - } \quad \text { No state support }\end{array}$ & $\begin{array}{l}\text { De-regulated water management: } \\
\text { - } \quad \text { Local water management } \\
\text { - WMOs incapable of implementing } \\
\text { water policies } \\
\text { - National policies de-linked from } \\
\text { local-level reality }\end{array}$ \\
\hline
\end{tabular}

Different correlations of the identified types of linkages between land ownership, agricultural policies and water systems are presented in all Central Asian countries. This variety led to the irrational use of water and land resources, and consequently increasing land degradation. Several different management types are presented below.

The first type of system is presented more in Uzbekistan and partly in Kazakhstan. After the collapse of the Soviet Union, water and land management systems in Uzbekistan more or less correlated to the previous Soviet model, i.e., hierarchic and centralized based on the top-down approach [18]. Water remains a state-owned resource and is distributed via state-owned networks [37]. The central planning system still exists and the state controls farmers by ordering crop production quantities. At the same time, Uzbekistan has been developing its trade and has legalized three different schemes of agricultural production: state-ordered production (cotton, wheat); commercial production (rice); household production of food crops [33,38].

After the collapse of the Soviet Union, land in Kazakhstan was divided into conditional land shares (CLSs) between the members of the former Sovkhozes and Kolkhozes based on a long-term lease (initially for 99 years; later changed to 49 years). CLSs were issued as "undefined common shares" and farmers could be unaware of the exact location and shape of the land plots to which they were entitled. Simultaneously, the water fund remains under state ownership. The government of Kazakhstan encourages the establishment of large farm enterprises and supports them. In the north of the country, large farms still exist and operate similarly to the Soviet "collective farms" model. Multiple land shareholders contributed their land shares as capital to establish such "farm enterprises" [39,40]. Re-structuring of land administration at various government levels took place, but there does not seem to be any clear process in place for the transition/transfer of obligations.

The third type of system is present in Kyrgyzstan and partly in Tajikistan [41]. Land distribution in these two countries started immediately after the collapse of the Soviet system. For example, in Kyrgyzstan, the 470 Kolkhozes and Sovkhozes were split into more than 30,000 small farms [16]. Initially, the agrarian reform was largely controlled by local administrations and depended on the in situ rules designed by respective governance entities. The burden of covering the Kolkhozes' and Sovkhozes' liabilities was placed on the newly established farms, and many of them achieved profitability [15]. Thus, in Kyrgyzstan, the system of land rights sale/transfer was introduced, giving birth to the new land market. At present, wealthier households prefer renting lands from poorer ones [16].

Land and water reforms in Tajikistan are still underway. During the Soviet era, $99 \%$ of agricultural land was owned by large state and collective farms, and 1\% was cultivated by households for subsistence purposes. The 1996 Land Code granted every household the permanent and heritable right to a $0.15-0.40$ ha plot. Such household—garden and/or kitchen—plots were generally given to 
the members of state and collective farms in the Soviet era. Tajikistan's government distributed these small land plots in two phases, corresponding to presidential decrees of 1995, 1996 and 1997.

\section{Conclusions}

In Central Asia, land and water rights systems are closely linked. After the collapse of the Soviet Union, the newly emerged states launched their respective water and land reforms. Transformations in the sphere of land ownership and rights had and continue to have longstanding impacts on water resources management and vice-versa.

Central Asian countries are making considerable efforts to control land degradation, including state control of land use and land quality, mapping of land categories, and monitoring of land degradation. Each country has a land cadaster (inventory) as a land control tool. Non-agricultural land acquisition policies are key for preventing the withdrawal of productive lands from agricultural use and recovering degraded land.

During the Soviet period, land in CA was deemed a means of production. The post-Soviet policies of Central Asian states mostly focus on food/crop exports and/or food self-sufficiency. Although recent reforms in the regions' countries resulted in individual or private ownership, land issues are still acute. In addition, the changes in the water sector did not produce sustainable links with land management. As a result, water rights are de-linked from land rights. Therefore, water resources planning and use models do not correspond to the actual condition and productivity of land. Mono-cropping and price/market-driven land use are still the mainstream land-use policies in CA countries with the governments focusing on production volumes. The function of monitoring the land condition lies with the same ministry which is responsible for agricultural production, i.e., the Ministry of Agriculture. Thus, state agricultural agencies are focusing more on promoting state agricultural production policies than land reclamation and rehabilitation efforts.

Agricultural policies are vital for designing and implementing land conservation measures. Coping with large-scale anthropogenic land degradation requires a shift in land governance and management policies and practices. Ownership schemes, land rights, linkages between water and land rights, and the introduction of incentives to preserve land resources all constitute important institutional factors. Nonetheless, Central Asian countries are still promoting policies that neglect land protection and the concept of "land as a production unit", resulting in the volume of degraded land growing every year.

The consequences, particularly in the contexts of economic and social aspects of land degradation, may help to see the issue as an institutional one and understand its socio-political scope. To reverse the trend, certain elements of land management require change allowing the application of economic incentives and building knowledge and capacities of immediate land- and water-users. New institutional approaches and solutions such as Water Users Associations and joint planning of land-water resources are the overarching factors to improve the situation in the land sector. Strong and sensible efforts to re-link water management and land ownership could also foster improved land degradation control.

Author Contributions: I.A. was responsible for the paper's concept and review of water and land policies. E.S. focused on the data analysis and wrote the sections on land degradation. T.R. gathered and analyzed data and linkages between land and water rights.

Funding: This research received no external funding.

Acknowledgments: The authors express their gratitude to the Regional Environmental Centre for Central Asia (CAREC) for the opportunity to conduct this research.

Conflicts of Interest: The authors declare no conflict of interest. 


\section{References}

1. Quillerou, E.; Thomas, R.J.; Guchgeldiyev, O.; Ettling, S.; Etter, H.; Stewart, N. (Eds.) Broadening Land Management Options for Improved Economic Sustainability across Central Asia: A Synthesis of National Studies; Central Asia Regional Report; The Economics of Land Degradation (ELD): Bonn, Germany, 2016. Available online: http: / / www.eld-initiative.org/index.php?id=133\&L=0 (accessed on 12 September 2018).

2. FAO. Drought Characteristics and Managements in Central Asia and Turkey; Food and Agriculture Organization of the United Nations (FAO): Rome, Italy, 2017; ISBN 978-92-5-109604-8. Available online: http:/ / www.droughtmanagement.info/literature/FAO_Drought_characteristics_and_Management_in_ CAsia_Turkey_2017.pdf (accessed on 12 September 2018).

3. Baartman, J.; Lynden, G.; Reed, M.; Ritsema, C.; Hessel, R. (Eds.) Desertification and Land Degradation: Origins, Processes and Solutions; Scientific Report 4; DESIRE Project: Wageningen, The Netherlands, 2007. Available online: http:/ /www.desire-his.eu/index.php/en/study-site-contexts/wp11-information-review-the maticmenu-165/515-desertification-and-land-degradation-executive-summary (accessed on 12 September 2018).

4. Bekturova, G.; Romanova, O. Traditional Land Management Knowledge in Central Asia; UNDP-GM: Banjul, Gambia, 2007; ISBN 9965-482-72-1.

5. Krasilnikov, P.; Konyushkova, M.; Vargas, R. Land Resources and Food Security of Central Asia and Southern Caucasus; Food and Agriculture Organization of the United Nations (FAO): Rome, Italy, 2016; ISBN 978-92-5-009329-1. Available online: http:/ / www.fao.org/3/a-i5914b.pdf (accessed on 12 September 2018).

6. Bodemeyer, R.; Fabian, A.; Starrost, I.; Trux, A. (Eds.) Acting Locally-Cooperating Regionally, Combating Desertification in Central Asia; GTZ—German Technical Cooperation: Bonn, Germany, 2007.

7. O'Neill, G. Land and water 'reform' in the 1920s-Agrarian revolution or social engineering? In Central Asia, Aspects of Transition; Everett-Heath, T., Ed.; Routledge Curzon: New York, NY, USA, 2003; pp. 54-75, ISBN 0-700-70956-8.

8. Spoor, M.; Krutov, A. The 'Power of Water' in a divided Central Asia. Perspect. Glob. Dev. Technol. 2003, 2, 593-614. [CrossRef]

9. Youlin, Y.; Jin, L.S.; Squires, V.; Kyung-soo, K.; Hye-min, P. (Eds.) Combating Desertification E Land Degradation: Proven Practices from Asia and the Pacific; Korea Forest Service: Changwon, Korea, 2011; ISBN 978-89-88960-11-093500.

10. Micklin, P. The Aral Sea Disaster. Annu. Rev. Earth Planet. Sci. 2007, 35, 47-72. [CrossRef]

11. O'Hara, S.L. Lessons from the past: Water management in Central Asia. Water Policy 2000, 2, 365-384. [CrossRef]

12. Saigal, S. Kazakhstan: Issues and Approaches to Combat Desertification; TA 5941-REG: Combating Desertification in Asia; ADB: Mandaluyong, Philippines, 2003.

13. Mirzabaev, A.; Goedecke, J.; Dubovyk, O.; Djanibekov, U.; Bao Le, Q.; Aw-Hassan, A. Chapter 10 Economics of Land Degradation in Central Asia. In Evaluating Global Land Degradation Using Ground-Based Measurements and Remote Sensing; Springer International Publishing: Berlin, Germany, 2016; pp. 261-290.

14. Dukhovny, V.A.; Sokolov, V.I.; Horst, M.G.; Sorokin, A.G.; Nazariy, A.M.; Galustyan, A.G. Dynamics of the Present Water Balance in the Fergana Valley; Collection of Scientific Papers; SIC ICWC: Tashkent, Uzbekistan, 2012; pp. 5-27.

15. Giovarelli, R. Land Reform and Farm Reorganization in the Kyrgyz Republic; RDI Reports on Foreign Aid and Development \#96; Rural Development Institute: Seattle, WA, USA, 1998; ISSN 1071-7099.

16. Savastano, S.; Scandizzo, P.L. Optimal farm size in an uncertain land market: The case of Kyrgyz Republic. Agric. Econ. 2009, 40, 745-758. [CrossRef]

17. Spoor, M. Agrarian transition in former Soviet Central Asia: A comparative study of Uzbekistan and Kyrgyzstan. J. Peasant Stud. 2008, 23, 46-63. [CrossRef]

18. Conti, P.J. Ties That Bind: The Traditional Irrigation Systems of Uzbekistan Social Capital and Implications for Current Successful Management; Paper 5830; UME EP36631; University of Montana: Missoula, MT, USA, 2004.

19. Abdullaev, I.; Rakhmatullaev, S. Central Asian irrigation sector in a climate change context: Some reflections. J. Water Clim. Chang. 2014, 5, 341-356. [CrossRef]

20. Sehring, J. Path Dependencies and Institutional Bricolage in Post-Soviet Water Governance. Water Altern. 2009, 2, 61-81.

21. Micklin, P. Managing Water in Central Asia. Central Asian and Caucasian Prospects; The Royal Institute of International Affair: London, UK, 2000; ISBN 1862030006. 
22. Abdullaev, I. Chapter I. Role of water managers of Central Asia in preventing water conflicts: Reduce and scattered. In Social-Technical Aspects of Water Resources Management in Central Asia; LAP LAMBERT Academic Publishing: Deutschland, Germany, 2012; ISBN 978-3-8484-4557-8.

23. Adbullaev, I.; Rakhmatullaev, S. Transformation of water management in Central Asia from State-centric, hydraulic mission to socio-political control. Environ. Earth Sci. 2015, 73, 849-861. [CrossRef]

24. Abdullaev, I.; Atabaeva, S. Water sector in Central Asia: Slow transformation and potential for cooperation. Int. J. Sustain. Soc. 2012, 4, 103-112. [CrossRef]

25. Noel, S.; Mikulcak, F.; Stewart, N.; Etter, H. Reaping economic and environmental benefits from sustainable land management. In Economics of Land Degradation Initiative: Report for Policy and Decision Makers; ELD: Bonn, Germany, 2015; ISBN 978-92-808-6063-4. Available online: http:/ / www.eld-initiative.org/fileadmin /pdf/ELD-pm-report_05_web_300dpi.pdf (accessed on 12 September 2018).

26. Abdullaev, I.; Mollinga, P.P. The socio-technical aspects of water management: Emerging trends at grass roots level in Uzbekistan. Water 2010, 2, 85-100. [CrossRef]

27. Dukhovny, V.; Mirzaev, N.; Sokolov, V. IWRM Implementation: Experiences with water sector reforms in Central Asia. In Central Asian Waters; Helsinki University of Technology: Espoo, Finland, 2008; pp. 19-31, ISBN 978-951-22-9593-7.

28. Aminova, M.; Abdullaev, I. Water Management in a State-Centered Environment: Water Governance Analysis of Uzbekistan. Sustainability 2009, 1, 1240-1265. [CrossRef]

29. Lamers, J.P.A.; Karimov, A.; Bekchanov, M. Impact of Water Availability on Land and Water Productivity: A Temporal and Spatial Analysis of the Case Study Region Khorezm, Uzbekistan. Water 2010, 2, 668-684. [CrossRef]

30. Spoor, M. The Aral See Basin Crisis: Transition and Environment in Former Soviet Central Asia. Dev. Chang. 1998, 29, 409-435. [CrossRef]

31. Statistical Yearbook for Asia and the Pacific 2014; United Nations Publications: New York, NY, USA, 2014; ISBN 9789211206876. Available online: http:/ /www.unescap.org/publications/statistical-yearbook-asia-a nd-pacific-2014 (accessed on 12 September 2018).

32. Spoor, M.; Visser, O. The State of Agrarian Reform in the Former Soviet Union. Eur.-Asia Stud. 2001, 53, 885-901. [CrossRef]

33. Veldwisch, G.J.; Spoor, M. Contesting Rural Resources: Emerging 'Forms' of Agrarian Production in Uzbekistan. J. Peasant Stud. 2008, 35, 424-451. [CrossRef]

34. Kandiyoti, D. Post-Soviet Institutional Design, NGOs and Rural Livelihoods in Uzbekistan; Civil Society and Social Movements Programme, Paper No. 11; United Nations Research Institute for Social Development: Geneva, Switzerland, 2004; ISSN 1020-8178.

35. Hodgson, S. Land and Water-The Right Interface; FAO Legislative Study \#84; FAO: Rome, Italy, 2004; ISBN 92-5-105214-X. Available online: http:/ / www.fao.org/3/a-y5692e.pdf (accessed on 12 September 2018).

36. Abdullaev, I.; Manthritilake, H.; Kazbekov, J. Water and Geopolitics in Central Asia: Problems and outlook. In The Last Drop? Water, Security and Sustainable Development in Central Eurasia; Arsel, M., Spoor, M., Eds.; Routledge: New York, NY, USA, 2010; pp. 125-143, ISBN 978-0-415-46161-0.

37. Lerman, Z.; Garcia-Garcia, J.; Wichelns, D. Land and Water Policies in Uzbekistan. Post-Sov. Geogr. Econ. 1996, 37, 145-174. [CrossRef]

38. Veldwisch, G.J.; Bock, B.B. Dehkans, Diversification and Dependencies: Rural Transformation in Post-Soviet Uzbekistan. J. Agrar. Chang. 2011, 11, 581-597. [CrossRef]

39. Land Code of the Republic of Kazakhstan Dated 20 June 2003, No. 442. Available online: http: / / online.zak on.kz/Document/?doc_id=1040583 (accessed on 12 September 2018).

40. Kazakhstan Land Administration Report; Prepared by ARD, Inc.; USAID: Washington, DC, USA, 2005. Available online: http://landportal.info/sites/landportal.info/files/kazakhstanlandadministration.pdf (accessed on 12 September 2018).

41. Lerman, Z.; Sedik, D. Agricultural Development and Household Incomes in Central Asia: A Survey of Tajikistan, 2003-2008. Eurasian Geogr. Econ. 2009, 50, 301-326. [CrossRef]

(C) 2018 by the authors. Licensee MDPI, Basel, Switzerland. This article is an open access article distributed under the terms and conditions of the Creative Commons Attribution (CC BY) license (http:/ / creativecommons.org/licenses/by/4.0/). 